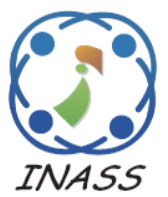

\title{
Kinetic Gas Molecular Optimization Method for PV System Under Partial Shaded Condition
}

\author{
Revuru Sarveswara Prasad ${ }^{1 *}$ \\ Rathinam Thiyagarajan ${ }^{2}$ \\ ${ }^{1}$ Lakireddy Bali Reddy College of Engineering, Mylavaram, India \\ ${ }^{2}$ Annamalai University, Chidambaram, India \\ * Corresponding author’s Email: sarveswarars@gmail.com
}

\begin{abstract}
In recent trends, increasing energy demands and environmental pollution are motivating researchers for technological investments related to renewable energy sources. The possibility of Partially Shaded Condition (PSC) is consistently high for a large scale Photo-Voltaic (PV) system. Under PSC, the Power-Voltage (P-V) curve exposes multiple peaks that decrease the efficiency of traditional Maximum Power Point Tracking (MPPT) methods. Also, Perturb and Observe (P\&O) gets trapped in one of the Local MPP, so it fails to recognize Global MPP from the PV. Subsequently, when partial shading occurs, its incident shadow diminishes the irradiation and reduces the generated power from the PV. Since, the conventional MPPT could not find the global maximum power of the P-V characteristic curve rapidly, a novel tracking process needs to be developed. In this paper, Kinetic Gas Molecular Optimization (KGMO)-based $\mathrm{P} \& \mathrm{O}$ algorithm for the PV system operating under PSC is proposed. The feasibility of this proposed method is verified for specified PV array model with Partially shaded irradiation conditions by simulation. The simulation results are obtained in Matlab/Simulink environment to validate the performance of the method. The proposed KGMO is compared with Ant Colony Optimization (ACO) in terms of power and maximum number of iterations. For the specified Partilly shaded irradiation conditions, ACO gives less power and takes more number of iterations when compared to the proposed KGMO technique. The results show that the KGMO algorithm can track the global MPP effectively, and is robust to various shading patterns. This method makes the implementation as cheap, simple and strong in the aspect of varying environmental circumstances and array characteristics, also it has least negative influence on the integrated power system.
\end{abstract}

Keywords: Kinetic gas molecular optimization, Maximum power point tracking, Partial shading conditions, Perturb and observe, Photo-voltaic.

\section{Introduction}

Nowadays, the economic development of a country depends largely on its effective electricity supply. For the past few years, most developing countries have been heading towards finding alternative energy sources for electricity and solar energy has emerged as the most popular energy source [1]. Solar energy is definitely a favourable energy because of its source obtainability all over the world and it has the benefit of meeting pollution free constraints [2]. On the other hand, the effectiveness of the energy is prominently dependent upon the irradiation level and Photo-Voltaic (PV) temperature [3]. But, PV arrays do not get uniform solar radiation throughout the day. During PSC, the traditional MPPT methods mostly fail at multiple maxima points due to the presence of bypass diodes, which is used to find out the formation of hot spots in the PV strings $[4,5]$. To control the multiple peak points during PSC, numerous enhanced MPPT methods are suggested [6]. Under these circumstances, MPPT control technique plays a significant role in efficiency improvement of PV systems [7]. MPPT developers proposed distinct strategies like Re-configurable MPPTs [8], cross diagonal configuration [9] which vary the interconnection between PV modules to decrease the unfavourable influence of PSC [10]. 
Recent meta-heuristic optimization algorithms named Grasshopper, Particle Swarm Optimization (PSO), Bat algorithm, Flower Pollination algorithm, Cuckoo Search algorithm, Harmony Search Algorithms are applicable for solving the reconfiguration process of the moderately shaded PV array optimally [11]. Many advanced methods based on the artificial intelligence like fuzzy logic control and Cat Swarm Optimization [12] are capable to monitor the global MPP other than the aforementioned methods. However, these methods are not feasible in real time complex environment because it requires massive training, broader experience [13] and also needs some genetic requirements such as minimum output power fluctuations, low cost \& complexity and capability to track rapidly when working condition deviates [14]. Therefore, a control strategy requires to be implemented which handles the duty cycle and always manages to extract the extreme power from the panel [15]. The optimization algorithm consists of varying the voltage reference or the converter input current. Afterward, the amount of power converted from the panel is measured. If the resultant power is greater than the previous measured power, the voltage reference is steadily increased in the same proportion, if not it is decreased. These steps are continually taken in order to find the optimum MPPT.

To compensate the aforementioned problems, this paper recommends a novel scheme which appropriately incorporates the characteristics of KGMO based P\&O. Kinetic Gas Molecule Optimization (KGMO) is a type of meta-heuristic optimization algorithm inspired by the law of thermodynamics and heat transfer. In this, search agents are gas molecules that interact with one another as well as with the surrounding to attain thermal equilibrium state. KGMO works similar to Particle Swarm Optimisation (PSO). The position update of gas agents is similar to PSO and in KGMO the kinetic energy parameter is used for measuring the performance. One advantage of KGMO is, quick convergence toward global optima. Primarily, KGMO will complete the global search after a determinate number of gas molecules. After that, it is employed to track the maximum target value rapidly to get the exact target value. Once the global MPP value is obtained, this solution is used to initialize $\mathrm{P} \& \mathrm{O}$ constraints. Finally, $\mathrm{P} \& \mathrm{O}$ algorithm modifies the global MPP. This feature not only having a simple control structure, but also it can track the MPP under various conditions. KGMO is referred as one of the most modest procedures for monitoring the MPP of a PV system under quick deviations of meteorological conditions where it is capable to assist promptly to these deviations. Furthermore, the proposed KGMO gives more power and simulates the output with a low computational time, insisting minimum disturbance to the load and needs less sensors to achieve MPP.

The organization of this research paper is given as follows: The literature survey of recent researches related to PSC is given in Section 2. Section 3 provides the problem statement and preliminaries, respectively. Section 4 describes the description about the proposed method. The performance and comparative result analysis of the proposed research work is described in the Section 5. Furthermore, the conclusion of this research work is made in Section 6.

\section{Literature review}

RozanaAlik, AwangJusoh [16] proposed an enhanced $\mathrm{P} \& \mathrm{O}$ algorithm for the impact of partial conditions on the Photo-Voltaic (PV) systems. The developed technique is beneficial for solar at every irradiation level with high proficiency of the structure. Furthermore, the major benefits of these approaches are low-cost, simple and accurate. Sometimes, $\mathrm{P} \& \mathrm{O}$ algorithm with large step size delivered the lowest tracking proficiency, so it gives more power loss during the tracking process.

A. SoufyaneBenyoucef, A. Chouder, K. Kara, and S. Silvestre [17] developed Artificial Bee Colony (ABC) based MPPT for photo-voltaic system that work under partially shaded condition. This technique is very robust, it uses few numbers of control factors and its convergence speed is independent of the preliminary conditions. The presented algorithm not only overcoming the general issues of the traditional MPPT approaches, but also gives a modest and a simple MPPT system. Although, ABC based MPPT procedure has a very slow convergence speed towards the GMPPT compared to PSO based MPPT system.

J. Qi, Y. Zhang, and Y. Chen [18] presented Adaptive MPPT approach for a solar cell under PSC to extract maximum power from the PV cell. This approach used AMPPT technique to discover the optimal global MPP for various partially shaded conditions to improve reliability of the system. When output characteristics of solar array varies, AMPPT method will regulate the tracking schemes to explore for Global Peak Area (GPA). If there is a large variance in power level between the local MPPs and global MPPs, it creates high power oscillation. 
M. Oulcaid, H.E. Fadil, A. Yahya, and F. Giri [19] presented P\&O based MPPT method for PV panel under PSC to extract maximum power form the PV. The proposed algorithm observes the voltage at MPP and activates a current-voltage sweep, due to this repeated sweep, and power loss has been minimized. However, after reaching the MPP, it starts deviating continuously, which produces a considerable amount of power losses.

P.S. Gavhane, S. Krishnamurthy, R. Dixit, J. Prasanth Ram, and N. Rajasekar [20] studied PV system under partially shaded situations using the Enhanced Leader Particle Swarm Optimization (ELPSO) algorithm. In this research, adjustments were made in the PSO to discover over-all finest particle in mutations for providing the search capability. These alterations update the particles in term of fastness that provides higher global convergence. One problem with the PSO technique is that the particles are incompatible with nearby particles due to lack of improbability. Additionally, in this method, computational complication is high when it is applied to solve high-dimensional and complex problems.

\section{Problem statement}

- Solar Panels help in maximum utilization of solar energy during the day. However, shading can have a huge impact on the performance of solar photovoltaic panels.

- During PSC, algorithms have either low or medium implementation complexity with a variable convergence speed.

- Due to partial shading, one part of the solar panel generates lower amount of energy as compared to the other non-shaded part. As the amount of power generated in shaded \& non shaded parts differs, it leads to overheating which in turn reduces the total power output of the solar panel.

\section{Proposed methodology}

Nowadays, KGMO based $\mathrm{P} \& \mathrm{O}$ have additional responsiveness in the research area of MPPT. This research paper shows that the proposed KGMO has an excellent feature than other algorithms under PSC. Table 1 represents Notation list for the proposed method.

\subsection{PV panel specification}

The PV farm consists of four PV arrays delivering each a maximum of $100 \mathrm{~kW}$ at $1000 \mathrm{~W} / \mathrm{m}^{2}$ sun
Table 1. Notation list

\begin{tabular}{|cl|}
\hline$C$ & Acceleration \\
$\mathrm{b}$ & Boltzmann's constant \\
$q$ & Charge \\
$I$ & Current \\
$d$ & Dimension \\
$E$ & Energy \\
$g$ & gap \\
$A$ & Ideality factor \\
$m$ & Mass \\
$o c$ & Open circuit \\
$s c$ & Short circuit \\
$S$ & Solar cell \\
$T$ & Temperature \\
$t$ & Time \\
$v$ & Velocity \\
$V$ & Voltage \\
\hline
\end{tabular}

irradiance. In recent years, solar manufacturers use POWER ON series from A2 peak which associates high quality power with advanced technologies. A single PV array block consists of 64 parallel strings where each string has 5 A2 Peak Power POWER ON P220-6x10 modules which are connected in series. Each PV panel is connected to boost (DC/DC) converter. The output of the boost converter is associated with a common DC bus of $500 \mathrm{~V}$. Each boost converter is regulated by individual MPPT.

A staircase current waveform is created on the I$\mathrm{V}$ curve, while the corresponding $\mathrm{P}-\mathrm{V}$ curve is characterized by multiple maxima points, as depicted in curve of Fig. 1. The specification table for PV panel is shown in below Table 2.

The solar power system is consisting of photovoltaic (PV) cells which is defined as an electrical device that transforms the light energy into power by using semiconducting materials with two variations such as crystalline and thin-film type. When the photon is absorbed by the semiconducting material, it converts the electromagnetic radiation of the solar spectrum to electricity with the help of photovoltaic effect. An electron requires more energy to participate in conduction to transform from its original state to free-state. The required energy is obtained from the band gap of the semiconductor which also considered as base energy which helps the electron to moves from the original state to free-state. The components such as diode, resistance and light created a source of the PV model are arranged in parallel connection. Photovoltaic energy generation system is given in the following Eqs. (1), (2), and (3). 
Array type: A2Peak Power POWER ON P220-6x10;
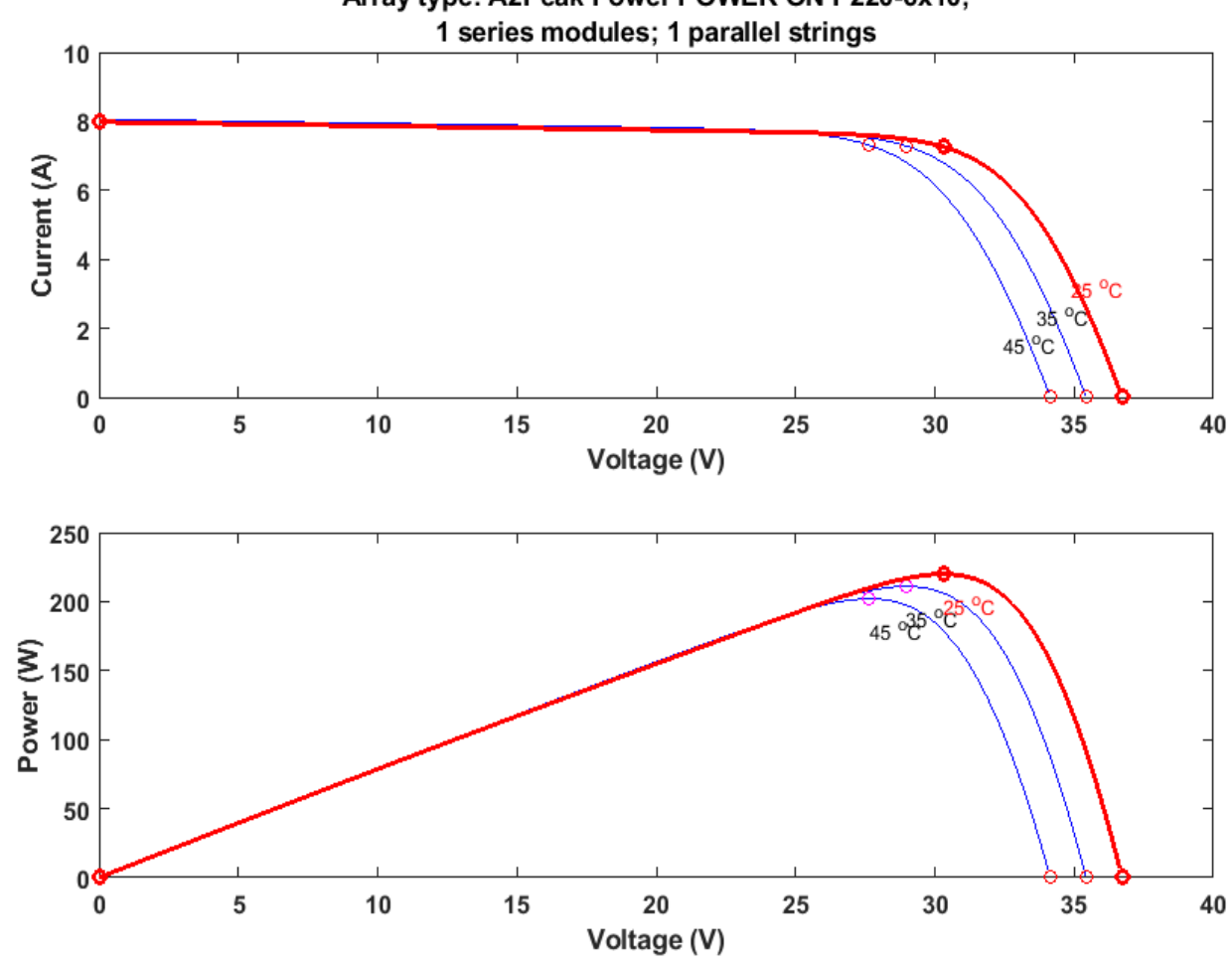

Figure.1 P-V \& I-V curve for multiple maxima points

Table 2. Specifications for PV panel

\begin{tabular}{|c|c|}
\hline Parameters & Value \\
\hline Maximum power & $219.978 \mathrm{~W}$ \\
\hline Open circuit voltage Voc & $36.72 \mathrm{~V}$ \\
\hline $\begin{array}{c}\text { Voltage at maximum power point } \\
\text { Vmp }\end{array}$ & 30.3 \\
\hline Temperature coefficient of Voc & $-0.35(\% /$ deg.C) \\
\hline Cells per module & $60 \mathrm{Ncell}$ \\
\hline Short-circuit current Isc & $7.98 \mathrm{~A}$ \\
\hline Current at maximum power point & $7.26 \mathrm{~A}$ \\
\hline Isc & $0.05(\% / \mathrm{deg} . \mathrm{C})$ \\
\hline Light generated current IL & $8.0041 \mathrm{~A}$ \\
\hline Diode saturation current & $1.8441 \times 10^{-10} \mathrm{~A}$ \\
\hline Diode ideality factor & 0.97472 \\
\hline Shunt resistance & $85.0716 \mathrm{ohms}$ \\
\hline Series resistance & $0.25728 \mathrm{ohms}$ \\
\hline
\end{tabular}

$$
\begin{aligned}
& I=I_{p h}-I_{d}\left[\exp \left(\frac{q V}{k_{b} T A}\right)-1\right] \\
& I_{p h}=S\left[I_{s c r}+k_{i}\left(T-T_{r}\right)\right] \\
& I_{d}=I_{r r}\left[\frac{T}{T_{r}}\right]^{3} \exp \left(\frac{q E_{g}}{k Q A}\left[\frac{1}{T_{r}}-\frac{1}{T}\right]\right)
\end{aligned}
$$

Where the value of $I$ represents the total current $(A)$, the value of output voltage is indicated by $V$, the temperature of the solar cell is represented as $T$, $q$ denotes the charge of the electron, the short-circuit temperature coefficient is signified as $k_{i}$. The irradiance of the solar cell is indicated as $S$, the open circuit voltage temperature coefficient is denoted as $k_{b}$, the Boltzmann's constant is indicated as $k$, an ideality factor represented as $A$. The load current and diode current denoted as $I_{p h}, I_{d}$ respectively. $I_{r r}$ represents the saturation current and short circuit current at reference condition is represented as $I_{s c r}$. The reference temperature is indicated as $T_{r}$. The total electron change is denoted as $Q$ and band gap energy indicated as $E_{g}$. Under PSC, the unshaded portion of the PV array obtains irradiation at definite level, even though the shaded portion receives less irradiation.

\subsection{KGMO based P\&O}

Kinetic Gas Molecule Optimization (KGMO) is a swarm-based algorithm for solving nonlinear problems, which works based on gas molecule theory [21]. The gas molecules are the agents in the search space and kinetic energy is used as the basis of performance measurement and control. Considering a system with agents (gas molecules), the position of the $i^{t h}$ agent is defined by Eq. (4). 


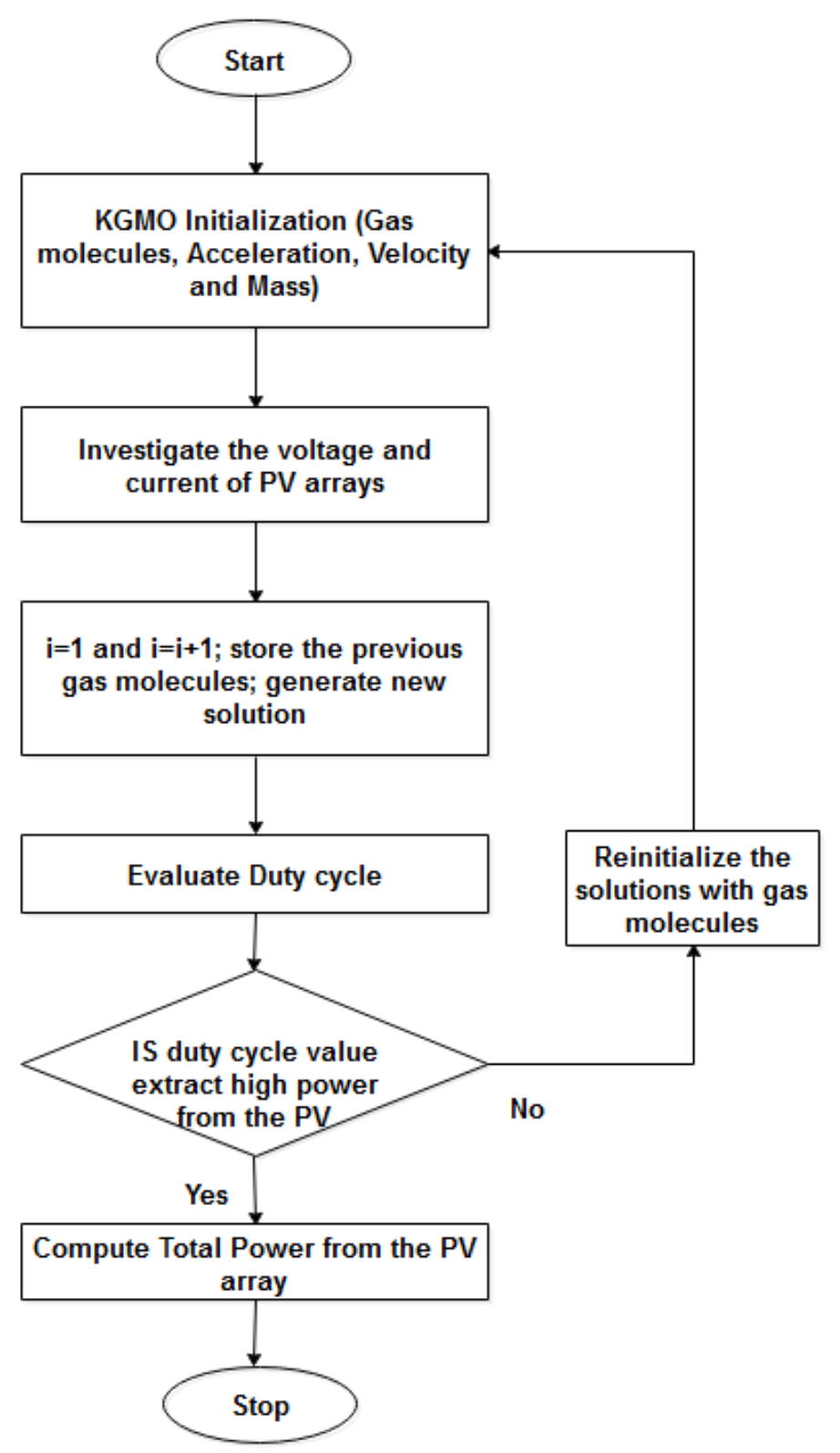

Figure.2 Flowchart for proposed KGMO

$$
X_{i}=\left(x_{i}^{1}, \ldots, x_{i}^{d}, \ldots x_{i}^{n}\right) \text { for } i=1,2, \ldots, N
$$

Where $x_{i}^{d}$ represents the position of the $i^{\text {th }}$ agent in the $d^{\text {th }}$ dimension and the velocity of the $i^{\text {th }}$ agent is presented by Eq. (5):

$$
V_{i}=\left(v_{i}^{1}, \ldots v_{i}^{d}, \ldots, v_{i}^{n}\right), \text { for }(i=1,2, \ldots, N)
$$

Where $v_{i}^{d}$ represents the velocity of the $i^{\text {th }}$ agent in the $d^{\text {th }}$ dimension. The kinetic energy is given by Eq. (6).

$$
\begin{aligned}
& \quad k_{i}^{d}(t)=\frac{3}{2} N b T_{i}^{d}(t), K_{i}=\left(k_{i}^{1}, \ldots k_{i}^{d}, \ldots, k_{i}^{n}\right), \text { for } \\
& (i=1,2, \ldots, N)
\end{aligned}
$$

Where $N$ is the number of gas molecules, $\mathrm{b}$ is the Boltzmann constant and $T_{i}^{d}(t)$ is the temperature of $i^{\text {th }}$ agent in the dth dimension at time $t$. (7).

The velocity of the molecule is updated by Eq.

$$
\begin{aligned}
& v_{i}^{d}(t+1)= \\
& T_{i}^{d}(t) w v_{i}^{d}(t)+C_{1} \operatorname{rand}_{i}(t)\left(\text { gbest }^{d}-\right. \\
& \left.x_{i}^{d}(t)\right)+C_{2} \operatorname{rand}_{i}(t)\left(\text { pbest }_{i}^{d}(t)-x_{i}^{d}(t)\right)
\end{aligned}
$$

Where $T_{i}^{d}(t)$ for converging molecules reduces exponentially over time, calculated as Eq. (8): 


$$
T_{i}^{d}(t)=0.95 \times T_{i}^{d}(t-1)
$$

The vector pbest $_{i}=$ $\left(\right.$ pbest $_{i}^{1}$, pbest $_{i}^{2}, \ldots$, pbest $\left._{i}^{n}\right)$ represents the best previous position of the $i^{\text {th }}$ gas molecule and gbest $=\left(\right.$ gbest $^{1}$, gbest $^{2}, \ldots$, gbest $\left.^{n}\right)$ is the best previous position amongst every molecules present in the container. The position and velocity of each particle are modified by arbitrary vectors which is existed within the equivalent assortments. $\left[-v_{\min }, v_{\max }\right]$ which is applied as the boundaries of the molecules. If $\left|v_{i}\right|>v_{\max }$, then $\left|v_{i}\right|=v_{\max } . w$ is referred as the inertia weight that reveals the resistance to slow down the gas movement. $\operatorname{rand}_{i}(t)$ is a uniform random variable in the interval $[0,1]$ at time $t$, used to deliver a randomized distinctive to the algorithm, where $C_{1}, C_{2}$ are mentioned as acceleration constants. The mass $m$ of each gas molecule is a random number within the range $0<m \leq 1$, which once identified remains constant throughout the execution of the algorithm as the container is assumed to contain only one type of gas at any one time. The random number is used to simulate different types of gases in different executions of the algorithm. From the above mentioned process, the position is updated for each unit of time interval by Eq. (9).

$$
x_{i}^{d}(\mathrm{t}+1)=\frac{\sqrt{2\left(\Delta k_{i}^{d}\right)}}{m}(t+1)+v_{i}^{d}(t+1) x_{i}^{d}(t)
$$

The minimum fitness function is found by using Eq. (10) and (11):

$$
\begin{aligned}
& \text { pbest }_{i}=f\left(x_{i}\right) \text { if } f\left(x_{i}\right)<f\left(\text { pbest }_{i}\right) \\
& \text { gbest }_{i}=f\left(x_{i}\right) \text { if } f\left(x_{i}\right)<f\left(\text { gbest }_{i}\right)
\end{aligned}
$$

Each gas molecule attempts to change its position $\left(x_{i}^{d}\right)$ using the distance between the current position and pbest $t_{i}^{d}$. The flowchart for the proposed KGMO is shown in Fig. 2.

\section{$5 \quad$ Result and discussion}

In this research, an efficient and fast hybrid MPPT for PV systems functioning under PSCs is developed. It combines a KGMO-based technique with $\mathrm{P} \& \mathrm{O}$ algorithm to track the MPP. This process has the benefit of simple control organization and is capable of quickly monitoring the global MPP during PSC. This work verified the proficiency of the proposed technique for monitoring the global MPP under different irradiance level. The proposed method designs the operating point on the stairs of I$\mathrm{V}$ curve (which occurs with partial shading) and applies a grouping of the calculated current value at every step to forecast the global MPP region. After that, $\mathrm{P} \& \mathrm{O}$ with uni-modal functions is used in the local area, so that the system achieves the global MPP. The Output change in PV is directly proportional to the irradiation change of $\mathrm{PV}$. To analyse the performance of simulation it's necessary to apply following modifications which is shown in below Table 2. The global MPP for base case PV module is shown in below Fig. 3 .

Additionally, by considering more complex shading patterns, the transient behaviour is established.The PV arrangement is simulated using Matlab/Simulink environment for KGMO based $\mathrm{P} \& \mathrm{O}$ which is shown in Fig.4. From the figures, the dissemination of the final power extracted from the PV system using our proposed MPP is located around the equivalent global MPP. The ability to find the global MPP for new weather conditions is very important especially for places with frequent weather changes. To demonstrate the tracking capability of the proposed KGMO-based $\mathrm{P} \& \mathrm{O}$ method under transient irradiance conditions, Various shading patterns are considered and evaluated. The four Shading Patterns (SPs) tested are listed in below Table 3 .

From the duty cycle pulses, switching generation for particular irradiation has to change to compensate the load demand. To evaluate the performances of the proposed MPPT controller during different irradiance levels, four shaded PV
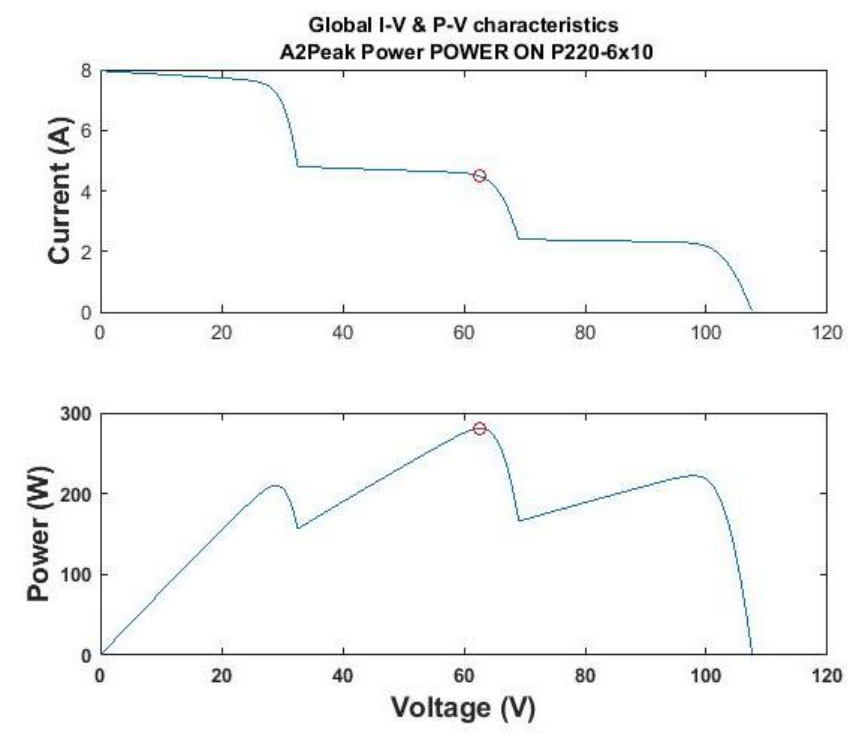

Figure.3 MPP curve for PV panel 


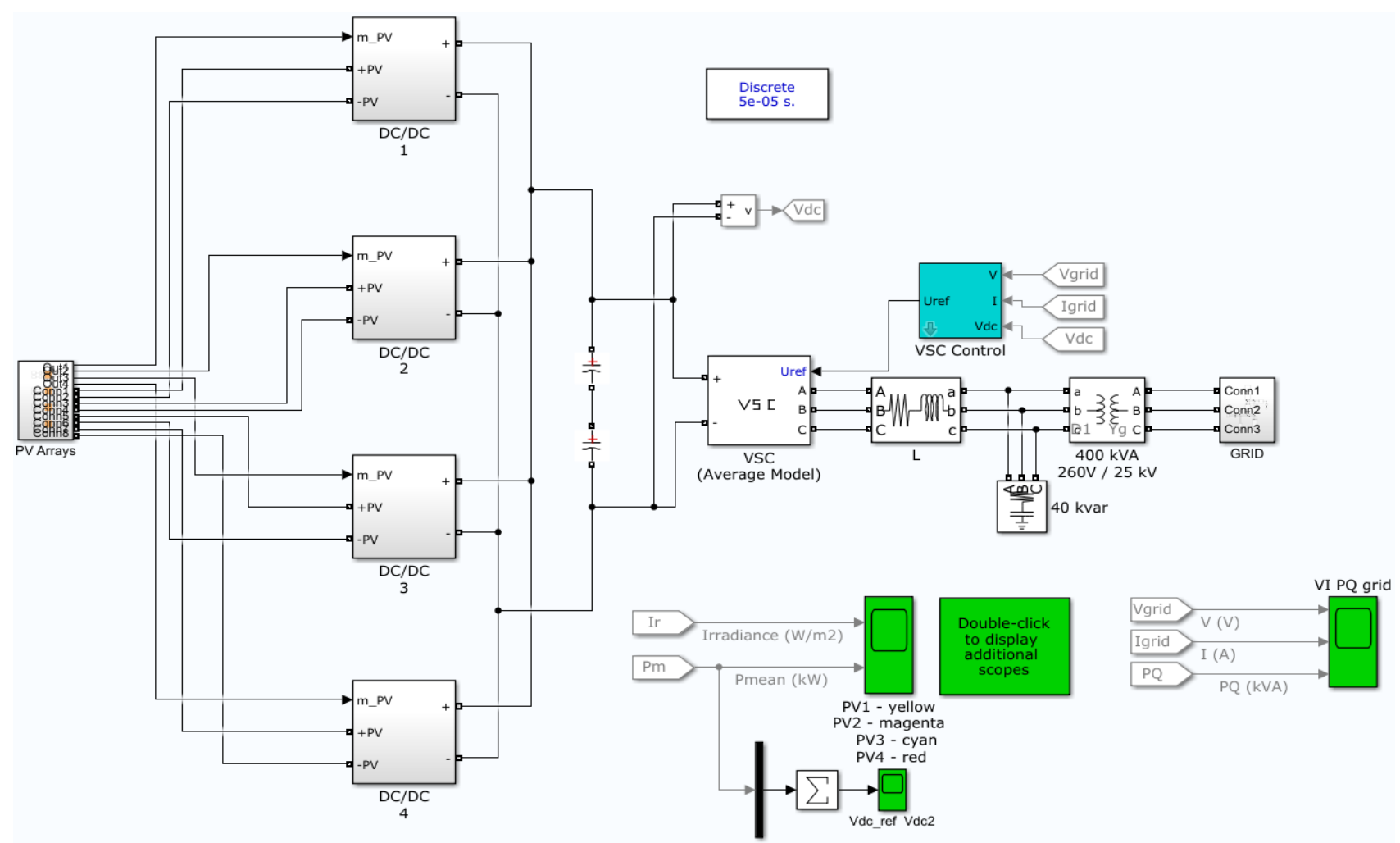

Figure.4 Simulink model for KGMO based P\&O

Table 3. Optimal power with base case scenario

\begin{tabular}{|c|c|}
\hline $\begin{array}{l}\text { Base case for PV panel with } \\
\text { irradiation and temperature level (A2 } \\
\text { Peak Power POWER ON P220-6x10 } \\
\text { modules) }\end{array}$ & $\begin{array}{l}\text { Output Power } \\
\text { (KW) }\end{array}$ \\
\hline $\begin{array}{c}\text { Panel Array } 1 \text { irradiation }=1000 \\
W / m^{2} \text { and Temperature }=25 \\
\text { degree c }\end{array}$ & $\begin{array}{c}\text { PV1 Power = } \\
65.321 \mathrm{KW}\end{array}$ \\
\hline $\begin{array}{c}\text { Panel Array } 2 \text { irradiation }=800 \\
W / m^{2} \text { and Temperature }=35 \text { degree } \\
\text { c }\end{array}$ & $\begin{array}{c}\text { PV2 Power }= \\
55.143 \mathrm{KW}\end{array}$ \\
\hline $\begin{array}{c}\text { Panel Array } 3 \text { irradiation }=700 \\
W / m^{2} \text { and Temperature }=45 \\
\text { degree c }\end{array}$ & $\begin{array}{c}\text { PV3 Power }= \\
38.572 \mathrm{KW}\end{array}$ \\
\hline $\begin{array}{c}\text { Panel Array } 4 \text { irradiation }=500 \\
W / m^{2} \text { and Temperature }=35 \\
\text { degree c }\end{array}$ & $\begin{array}{c}\text { PV4 Power = } \\
30.822 \mathrm{KW} \\
\text { Total Power }= \\
189.86 \mathrm{KW}\end{array}$ \\
\hline
\end{tabular}

modules receive $1000 \mathrm{~W} / \mathrm{m}^{2}, 800 \mathrm{~W} / \mathrm{m}^{2}, 700$ $\mathrm{W} / \mathrm{m}^{2}$ and $500 \mathrm{~W} / \mathrm{m}^{2}$ with total power of 189.51 $\mathrm{KW}$. From the output $\mathrm{P}-\mathrm{V}$ characteristic curve of the PV generator depicted in above figures. MPPT controller has the ability to distinguish between the global peak (GMPP) and local peak (LMPP).

The base case PV power for initial condition is shown in Fig. 5. The global MPP is the unique point where the maximum power on the $\mathrm{P}-\mathrm{V}$ curve occurs.

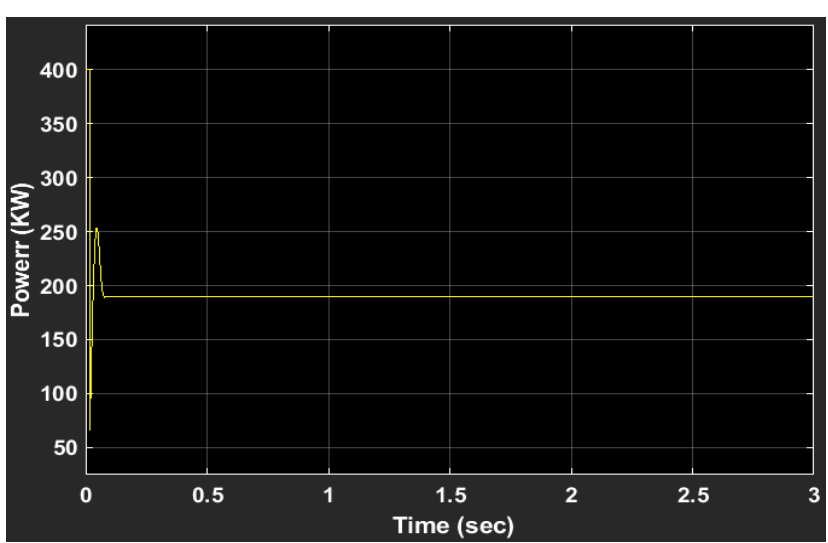

Figure.5 PV Power at base conditions

For comparison purposes, we calculate the global MPP by finding the point with the maximum power from the generated P-V curve. By applying the proposed algorithm for these two cases which is mentioned in Table 4 and 5, voltage and current in each PV and the maximum power is extracted under PSC. From this table, it shows that the implemented KGMO based P\&O can track the global MPP so that the power output is almost the same as the ideal power under all four shading patterns.

The performances are evaluated in terms of total power which are detailed in comparison tables. From the Table 4 (scenario 1), different irradiance levels for four shaded PV modules receives 1000 
Table 4. Comparison of base cases

\begin{tabular}{|c|c|}
\hline $\begin{array}{l}\text { Base case for PV panel } \\
\text { with irradiation and } \\
\text { temperature level (A2 Peak } \\
\text { Power POWER ON P220- } \\
\text { 6x10 modules) }\end{array}$ & $\begin{array}{l}\text { KGMO based MPPT (A2 } \\
\text { Peak Power POWER ON } \\
\text { P220-6x10 modules) }\end{array}$ \\
\hline \multicolumn{2}{|c|}{$\begin{array}{r}\text { Sceanrio 1 } \\
\end{array}$} \\
\hline $\begin{array}{c}\text { Panel Array } 1 \text { irradiation }= \\
1000 \mathrm{~W} / \mathrm{m}^{2} \\
\end{array}$ & $\begin{array}{c}\text { Panel Array } 1 \text { irradiation }= \\
1000 \mathrm{~W} / \mathrm{m}^{2}\end{array}$ \\
\hline $\begin{array}{c}\text { Panel Array } 2 \text { irradiation }= \\
800 \mathrm{~W} / \mathrm{m}^{2} \text { and }\end{array}$ & $\begin{array}{c}\text { Panel Array } 2 \text { irradiation }= \\
800 \mathrm{~W} / \mathrm{m}^{2} \text { and }\end{array}$ \\
\hline $\begin{array}{c}\text { Panel Array } 3 \text { irradiation }= \\
700 \mathrm{~W} / \mathrm{m}^{2} \text { and }\end{array}$ & $\begin{array}{c}\text { Panel Array } 3 \text { irradiation }= \\
700 \mathrm{~W} / \mathrm{m}^{2} \text { and }\end{array}$ \\
\hline $\begin{array}{c}\text { Panel Array } 4 \text { irradiation }= \\
500 \mathrm{~W} / \mathrm{m}^{2} \text { and } \\
\text { Total PV Power }=189.51 \\
\mathrm{KW}\end{array}$ & $\begin{array}{c}\text { Panel Array } 4 \text { irradiation }= \\
500 \mathrm{~W} / \mathrm{m}^{2} \text { and } \\
\text { Total PV Power }=537.168 \\
\mathrm{KW}\end{array}$ \\
\hline \multicolumn{2}{|c|}{\begin{tabular}{|l} 
Scenario 2 \\
\end{tabular}} \\
\hline $\begin{array}{c}\text { Panel Array } 1 \text { irradiation }= \\
1000 \mathrm{~W} / \mathrm{m}^{2}\end{array}$ & $\begin{array}{l}\text { Panel Array } 1 \text { irradiation }= \\
1000 \mathrm{~W} / \mathrm{m}^{2}\end{array}$ \\
\hline $\begin{array}{c}\text { Panel Array } 2 \text { irradiation }= \\
800 \mathrm{~W} / \mathrm{m}^{2} \text { and }\end{array}$ & $\begin{array}{c}\text { Panel Array } 2 \text { irradiation }= \\
800 \mathrm{~W} / \mathrm{m}^{2} \text { and }\end{array}$ \\
\hline $\begin{array}{c}\text { Panel Array } 3 \text { irradiation }= \\
200 \mathrm{~W} / \mathrm{m}^{2} \text { and }\end{array}$ & $\begin{array}{c}\text { Panel Array } 3 \text { irradiation }= \\
200 \mathrm{~W} / \mathrm{m}^{2} \text { and }\end{array}$ \\
\hline $\begin{array}{c}\text { Panel Array } 4 \text { irradiation }= \\
600 \mathrm{~W} / \mathrm{m}^{2} \text { and } \\
\text { Total PV Power }=160.95 \\
\text { KW }\end{array}$ & $\begin{array}{c}\text { Panel Array } 4 \text { irradiation }= \\
600 \mathrm{~W} / \mathrm{m}^{2} \text { and } \\
\text { Total PV Power }=456.531 \\
\mathrm{KW}\end{array}$ \\
\hline
\end{tabular}

Table 5. Comparative performance with ACO Algorithm \begin{tabular}{l|l} 
ACO based MPPT (A2 & KGMO based MPPT (A2
\end{tabular} Peak Power POWER ON Peak Power POWER ON P220-6x10 modules) $\quad$ P220-6x10 modules)

\begin{tabular}{|c|c|}
\hline \multicolumn{2}{|c|}{ Scenario 3} \\
\hline $\begin{array}{c}\text { Panel Array } 1 \text { irradiation }= \\
1000 \mathrm{~W} / \mathrm{m}^{2}\end{array}$ & $\begin{array}{c}\text { Panel Array } 1 \text { irradiation }= \\
1000 \mathrm{~W} / \mathrm{m}^{2}\end{array}$ \\
\hline $\begin{array}{c}\text { Panel Array } 2 \text { irradiation }= \\
800 \mathrm{~W} / \mathrm{m}^{2} \text { and }\end{array}$ & $\begin{array}{c}\text { Panel Array } 2 \text { irradiation }= \\
800 \mathrm{~W} / \mathrm{m}^{2} \text { and }\end{array}$ \\
\hline $\begin{array}{c}\text { Panel Array } 3 \text { irradiation }= \\
700 \mathrm{~W} / \mathrm{m}^{2} \text { and }\end{array}$ & $\begin{array}{c}\text { Panel Array } 3 \text { irradiation }= \\
700 \mathrm{~W} / \mathrm{m}^{2} \text { and }\end{array}$ \\
\hline $\begin{array}{l}\text { Panel Array } 4 \text { irradiation }= \\
500 \mathrm{~W} / \mathrm{m}^{2} \text { and }\end{array}$ & $\begin{array}{l}\text { Panel Array } 4 \text { irradiation }= \\
500 \mathrm{~W} / \mathrm{m}^{2} \text { and }\end{array}$ \\
\hline $\begin{array}{c}\text { Total PV Power }=454.50 \\
\text { KW }\end{array}$ & $\begin{array}{c}\text { Total PV Power }=537.168 \\
\text { KW }\end{array}$ \\
\hline \multicolumn{2}{|c|}{ Scenario 4} \\
\hline $\begin{array}{c}\text { Panel Array } 1 \text { irradiation }= \\
1000 \mathrm{~W} / \mathrm{m}^{2} \\
\end{array}$ & $\begin{array}{c}\text { Panel Array } 1 \text { irradiation }= \\
1000 \mathrm{~W} / \mathrm{m}^{2}\end{array}$ \\
\hline $\begin{array}{c}\text { Panel Array } 2 \text { irradiation }= \\
800 \mathrm{~W} / \mathrm{m}^{2} \text { and }\end{array}$ & $\begin{array}{c}\text { Panel Array } 2 \text { irradiation }= \\
800 \mathrm{~W} / \mathrm{m}^{2} \text { and }\end{array}$ \\
\hline $\begin{array}{c}\text { Panel Array } 3 \text { irradiation }= \\
200 \mathrm{~W} / \mathrm{m}^{2} \text { and }\end{array}$ & $\begin{array}{c}\text { Panel Array } 3 \text { irradiation }= \\
200 \mathrm{~W} / \mathrm{m}^{2} \text { and }\end{array}$ \\
\hline $\begin{array}{c}\text { Panel Array } 4 \text { irradiation }= \\
600 \mathrm{~W} / \mathrm{m}^{2} \text { and } \\
\text { Total PV Power }=372.31 \\
\text { KW }\end{array}$ & $\begin{array}{c}\text { Panel Array } 4 \text { irradiation }= \\
600 \mathrm{~W} / \mathrm{m}^{2} \text { and } \\
\text { Total PV Power }=456.531 \\
\text { KW }\end{array}$ \\
\hline
\end{tabular}

$\mathrm{W} / \mathrm{m}^{2}, 800 \mathrm{~W} / \mathrm{m}^{2}, 700 \mathrm{~W} / \mathrm{m}^{2}$ and $500 \mathrm{~W} / \mathrm{m}^{2}$ for that it receives total power of $189.51 \mathrm{KW}$. The proposed KGMO achieves the total power of $537.168 \mathrm{KW}$. For scenario 2, PV panel receives $1000 \mathrm{~W} / \mathrm{m}^{2}, 800 \mathrm{~W} / \mathrm{m}^{2}, 200 \mathrm{~W} / \mathrm{m}^{2}$ and 600 $W / m^{2}$ with total power of $160.95 \mathrm{KW}$. While KGMO attains $456.531 \mathrm{KW}$. The performance is compared with ACO under PSC because, ACO is a probabilistic control strategy which gives faster response speed with higher probability. So, initially the same specification of PV system is executed with ACO algorithm. Mainly, the presentation of the ACO in the area of PV systems gathered more responsiveness, for the upcoming purposes. ACO requires longer tracking time in the calculation of the pheromone update equation of the algorithm. The performances are evaluated in terms of total power which are detailed in following comparison tables.

The comparison for ACO based MPPT with proposed KGMO is in above Table 5. From the table (scenario 3), different irradiance levels for four shaded PV modules receives $1000 \mathrm{~W} / \mathrm{m}^{2}, 800$ $\mathrm{W} / \mathrm{m}^{2}, 700 \mathrm{~W} / \mathrm{m}^{2}$ and $500 \mathrm{~W} / \mathrm{m}^{2}$, ACO method produces total power of $454.50 \mathrm{KW}$ which is shown in above Fig. 6. The proposed KGMO achieves the

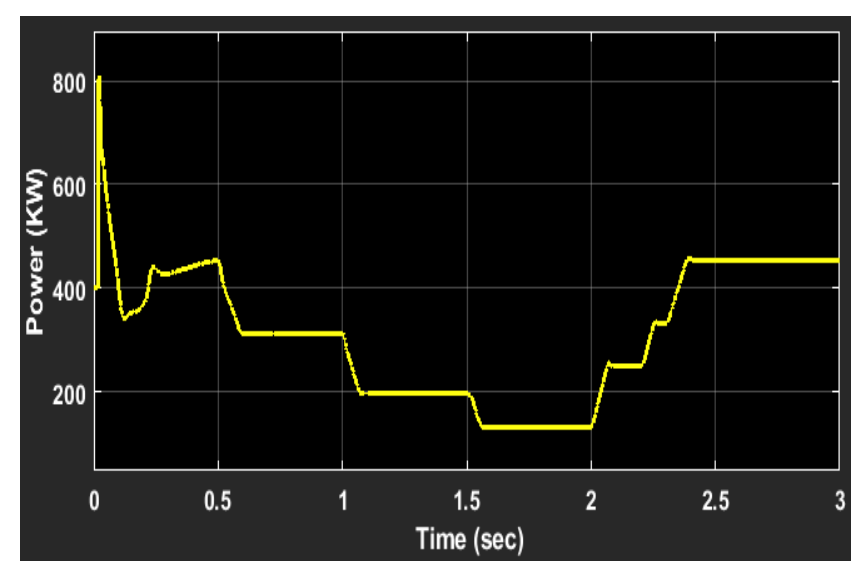

Figure.6 PV power for ACO at Scenario 3

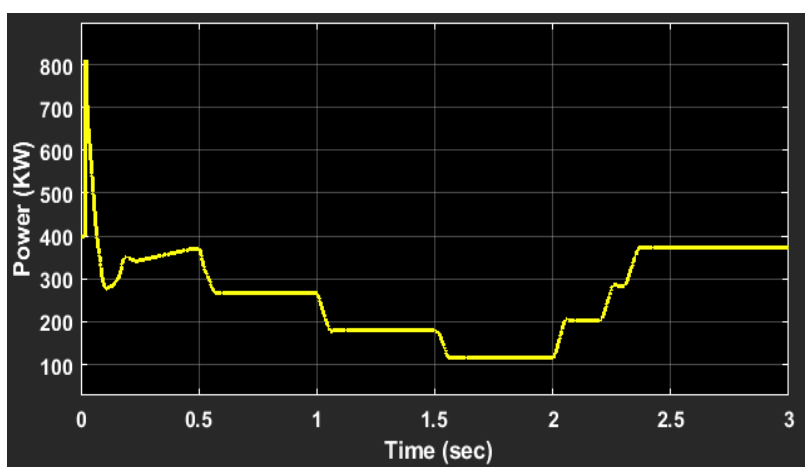

Figure.7 PV power for ACO at Scenario 4 
Table 6. Comparative analysis with ABC Algorithm [17]

\begin{tabular}{|c|c|}
\hline ABC based MPPT [17] (PV Module (BP- 380)) & KGMO based MPPT (PV Module (BP- 380)) \\
\hline \multicolumn{2}{|c|}{ Scenario 3 } \\
\hline Panel Array 1 irradiation $=1000 \mathrm{~W} / \mathrm{m}^{2}$ & Panel Array 1 irradiation $=1000 \mathrm{~W} / \mathrm{m}^{2}$ \\
\hline Panel Array 2 irradiation $=700 \mathrm{~W} / \mathrm{m}^{2}$ and & Panel Array 2 irradiation $=700 \mathrm{~W} / \mathrm{m}^{2}$ and \\
\hline Panel Array 3 irradiation $=100 \mathrm{~W} / \mathrm{m}^{2}$ and & Panel Array 3 irradiation $=100 \mathrm{~W} / \mathrm{m}^{2}$ and \\
\hline $\begin{array}{c}\text { Panel Array 4 irradiation }=1000 \mathrm{~W} / \mathrm{m}^{2} \text { and } \\
\text { Total PV Power }=88.377 \mathrm{~W}\end{array}$ & $\begin{array}{c}\text { Panel Array 4 irradiation }=1000 \mathrm{~W} / \mathrm{m}^{2} \text { and } \\
\text { Total PV Power }=93.626 \mathrm{~W}\end{array}$ \\
\hline \multicolumn{2}{|c|}{ Scenario 4 } \\
\hline Panel Array 1 irradiation $=1000 \mathrm{~W} / \mathrm{m}^{2}$ & Panel Array 1 irradiation $=1000 \mathrm{~W} / \mathrm{m}^{2}$ \\
\hline Panel Array 2 irradiation $=500 \mathrm{~W} / \mathrm{m}^{2}$ and & Panel Array 2 irradiation $=500 \mathrm{~W} / \mathrm{m}^{2}$ and \\
\hline Panel Array 3 irradiation $=100 \mathrm{~W} / \mathrm{m}^{2}$ and & Panel Array 3 irradiation $=100 \mathrm{~W} / \mathrm{m}^{2}$ and \\
\hline $\begin{array}{c}\text { Panel Array } 4 \text { irradiation }=1000 \mathrm{~W} / \mathrm{m}^{2} \text { and } \\
\text { Total PV Power }=73.976 \mathrm{~W}\end{array}$ & Panel Array 4 irradiation $=1000 \mathrm{~W} / \mathrm{m}^{2}$ and \\
\hline
\end{tabular}

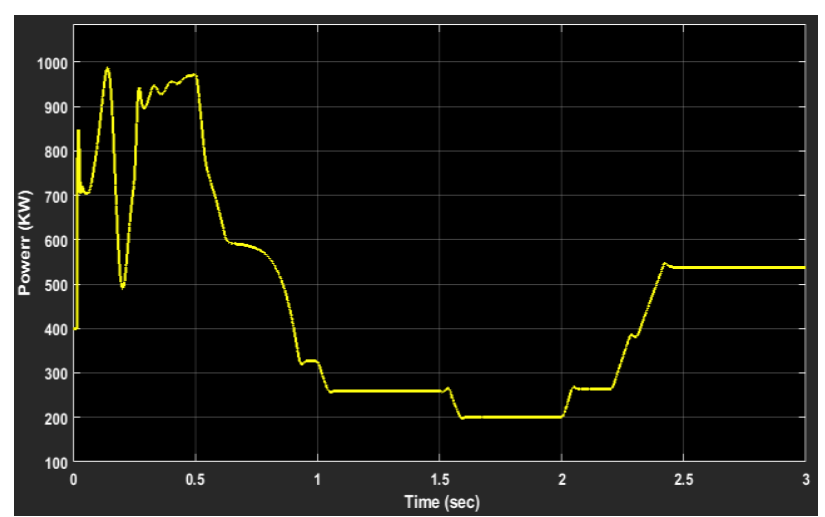

Figure.8 PV power for KGMO at Scenario 3

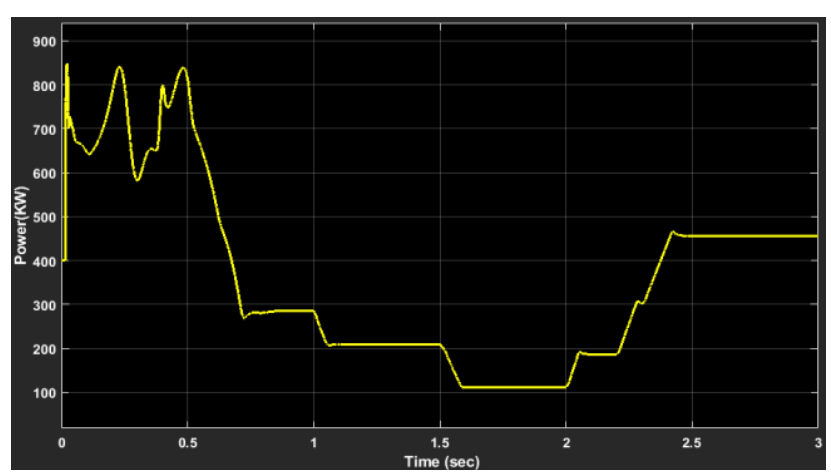

Figure.9 PV power for KGMO at Scenario 4

Table 7. Specifications for KGMO

\begin{tabular}{|c|c|}
\hline Parameters & Values \\
\hline Number of gas molecules (m) & 50 \\
\hline Number of parameters (N) & 18 \\
\hline Boltzmann constant (b) & $1.3806488 \times 10^{-23}$ \\
\hline Inertia Weight (w) & 0.4500 \\
\hline Acceleration Coefficient (C1, C2) & $1.2,2$ \\
\hline Number of Iterations (i) & 12 \\
\hline
\end{tabular}

total power of $537.168 \mathrm{KW}$. For scenario 4, PV panel receives $1000 \mathrm{~W} / \mathrm{m}^{2}, 800 \mathrm{~W} / \mathrm{m}^{2}, 200 \mathrm{~W} / \mathrm{m}^{2}$ and $600 \mathrm{~W} / \mathrm{m}^{2}$, ACO method produces total power of $372.31 \mathrm{KW}$ which is shown in above Fig. 7. While KGMO attains $456.531 \mathrm{KW}$ which is shown in Figs. 8 and 9.

Comparison table for other existing techniques is shown in above Table 6 . The results show the characteristic curve of PV panel determined by KGMO and the output power for different shading patterns correspondingly. Furthermore, Table 6 shows the comparison results for other PV model (PV Module BP - 380) with Artificial Bee Colony (ABC) which is described in [17]. From the comparison results, it clearly shows that proposed KGMO attains more power when compared to ABC method [17]. In the meantime, the proposed KGMO based $\mathrm{P} \& \mathrm{O}$ control has the capacity to identify the true peak among the multiple local peaks. Compared to other MPPT algorithms, the proposed method able to track the global MPP and generate a significantly increased energy output. Because of this, the tracking time reduced significantly. In addition, the energy produced by the proposed hybrid MPPT is higher than that of the conventional MPPT algorithms.

The specification table for KGMO is shown in Table 7. From the simulation results, Convergence speed for KGMO is much better than implemented ACO based MPPT. By simulating all the cases, ACO based $\mathrm{P} \& \mathrm{O}$ requires the average iterations to converge MPP was 15 iterations. But KGMO requires 12 iterations to reach the global maximum point. Subsequently the sampling time period of the MPPT method stimulates the tracking speed and it must be decided properly. This means that it can find the global MPP in a very short response time. This capability of fast response is very significant 
for the systems located where there are rapidly changing irradiance conditions.

\section{Conclusion}

This research work shows that the maximum power can be extracted by using the proposed KGMO technique with the traditional $\mathrm{P} \& \mathrm{O}$ algorithm under PSC. The conventional techniques are unable to identify the extreme power point under quickly varying insolation environments. Therefore, these procedures cannot be applied in PV system to obtain maximum accessible PV power. To enhance the tracking speed of the system, a simple and efficient KGMO method is used to reinitialize the particles to search for the new MPP, resulting in superior dynamic response. The results show that the proposed KGMO can efficiently track the global maximum power point under various shading patterns with much better tracking accuracy than the other compared methods. From the results, proposed method gives around 537.168 KW at different irradiation conditions with improved stability. As a conclusion, the proposed KGMO is a promising method, since it is able to cope under real variation of irradiations for achieving better results. The recommended method could be directly prolonged to protect different operative ranges of the specified $\mathrm{PV}$. In the future, the proposed method can also be applied to relatively large scale PV with large module strings. It could even be applied at the higher level in distributed PV systems with an MPPT on each PV module to eliminate modular level shading effects.

\section{References}

[1] Elmelegi, M. Aly, E.M. Ahmed, and A.G. Alharbi, "A simplified phase-shift PWM-based feedforward distributed MPPT method for gridconnected cascaded PV inverters", Solar Energy, Vol. 187, pp. 1-12, 2019.

[2] H. Yatimi, Y. Ouberri, and E. Aroudam, "Enhancement of Power Production of an Autonomous PV System Based on Robust MPPT Technique", Procedia Manufacturing, Vol. 32, pp. 397-404, 2019.

[3] A.D. Martin, J.R. Vazquez, and J.M. Cano, "MPPT in PV systems under partial shading conditions using artificial vision", Electric Power Systems Research, Vol. 162, pp. 89-98, 2018.

[4] P. Soulatiantork, "Performance comparison of a two PV module experimental setup using a modified MPPT algorithm under real outdoor conditions", Solar Energy, Vol. 169, pp. 401410, 2018.

[5] B. Paranthagan, M. Marimuthu, and $M$. Karthiga, "Global maximum power point tracking under partial shading condition using SEPIC converter", Int. J. Adv. Res. Electr. Electron. Instrum. Eng, Vol. 4, No. 2, pp. 718726, 2015.

[6] A. Elgammal and M. El-Naggar, "Energy management in smart grids for the integration of hybrid wind-PV-FC-battery renewable energy resources using multi-objective particle swarm optimisation (MOPSO)", The Journal of Engineering, Vol. 11, pp. 1806-1816, 2018.

[7] F. Belhachat and C. Larbes, "A review of global maximum power point tracking techniques of photovoltaic system under partial shading conditions", Renewable and Sustainable Energy Reviews, Vol. 92, pp. 513553, 2018.

[8] S. Malathy, and R. Ramaprabha, "Reconfiguration strategies to extract maximum power from photovoltaic array under partially shaded conditions", Renewable and Sustainable Energy Reviews, Vol. 81, pp. 29222934, 2017.

[9] M. J. Bosco, and M. C. Mabel, "A novel cross diagonal view configuration of a PV system under partial shading condition", Solar Energy, Vol. 158 pp. 760-773, 2017.

[10] R. Ahmad, A. F. Murtaza, U. T. Shami, and F. Spertino, "An MPPT technique for unshaded/shaded photovoltaic array based on transient evolution of series capacitor", Solar Energy, Vol. 157, pp. 377-389, 2017.

[11] F. Ahmed, "Recent meta-heuristic grasshopper optimization algorithm for optimal reconfiguration of partially shaded PV array", Solar Energy, Vol. 171, pp. 638-651, 2018.

[12] L. Guo, Z. Meng, Y. Sun, and L. Wang, "A modified cat swarm optimization based maximum power point tracking method for photovoltaic system under partially shaded condition", Energy, Vol. 144, pp. 501-514, 2018.

[13] P. Kofinas, I. A. Dounis, G. Papadakis, and M. N. Assimakopoulos, "An Intelligent MPPT controller based on direct neural control for partially shaded PV system", Energy and Buildings, Vol. 90, pp. 51-64, 2015.

[14] C. C. Chu and C. L. Chen, "Robust maximum power point tracking method for photovoltaic cells: a sliding mode control approach", Solar Energy, Vol. 83, No. 8, pp. 1370-1378, 2009. 
[15] M. J. Khan and L. Mathew, "Fuzzy logic controller-based MPPT for hybrid photovoltaic/wind/fuel cell power system", Neural Computing and Applications, Vol. 31, No. 10, pp. 6331-6344, 2019.

[16] R. Alik and A. Jusoh, "An enhanced P\&O checking algorithm MPPT for high tracking efficiency of partially shaded PV module", Solar Energy, Vol. 163, pp. 570-580, 2018.

[17] A. S. Benyoucef, A. Chouder, K. Kara, and S. Silvestre, "Artificial bee colony based algorithm for maximum power point tracking (MPPT) for PV systems operating under partial shaded conditions", Applied Soft Computing, Vol. 32, pp. 38-48, 2015.

[18] J. Qi, Y. Zhang, and Y. Chen, "Modeling and maximum power point tracking (MPPT) method for PV array under partial shade conditions", Renewable Energy, Vol. 66, pp. 337-345, 2014.

[19] M. Oulcaid, H.E. Fadil, A. Yahya, and F. Giri, "Maximum power point tracking algorithm for photovoltaic systems under partial shaded conditions", IFAC-PapersOnLine, Vol. 49, No. 13, pp. 217-222, 2016.

[20] P.S. Gavhane, S. Krishnamurthy, R. Dixit, J. Prasanth Ram, and N. Rajasekar, "EL-PSO based MPPT for solar PV under partial shaded condition", Energy Procedia, Vol. 117, pp. 1047-1053, 2017.

[21] S. Moein, and R. Logeswaran, "KGMO: A swarm optimization algorithm based on the kinetic energy of gas molecules", Information Sciences, Vol. 275, pp. 127-144, 2014. 